\title{
Mesozooplankton consumption of microplankton in the Mississippi River plume, with special emphasis on planktonic ciliates
}

\author{
Hongbin Liu ${ }^{1, *}$, Michael J. Dagg ${ }^{1}$, Chih-Jung Wu ${ }^{2}$, Kuo-Ping Chiang ${ }^{2}$ \\ ${ }^{1}$ Louisiana Universities Marine Consortium, 8124 Highway 56, Chauvin, Louisiana 70344, USA \\ ${ }^{2}$ Department of Environmental Biology and Fishery Science, National Taiwan Ocean University, Keelung 202-204, \\ Taiwan, ROC
}

\begin{abstract}
Grazing of mesozooplankton on phytoplankton, ciliates and other microplankton in the Mississippi River plume was studied by on-deck zooplankton addition incubations during March 2002. Diatoms, numerically predominated by the pennate diatom Pseudonitzschia pseudodelicatissima, were the most abundant microplankton in the plume. We observed that large cells of all types dominated the mesozooplankton diet and that phytoplankton generally comprised the largest dietary component. Microzooplankton contributed between 2 and $60 \%$ to the mesozooplankton diet. At the near-field station (nearest the discharge point of the river), $P$. pseudodelicatissimi concentration was low and consumption of diatoms, ciliates and dinoflagellates by mesozooplankton reflected available concentrations. In the mid-field stations, $P$. pseudodelicatissimi attained very high concentrations $\left(17000\right.$ cells $\left.\mathrm{ml}^{-1}\right)$ but comprised only a small portion of the mesozooplankton diet, which was instead dominated by ciliates and dinoflagellates. At the far-field station (approximately $60 \mathrm{~km}$ distance from the discharge point), $P$. pseudodelicatissimi concentration was intermediate but mesozooplankton clearance rates were still higher on ciliates and dinoflagellates at these stations. This pattern may have been established by changes in the composition of the mesozooplankton grazer community, by the inability of some mesozoopllankton to efficiently ingest the long $(>100 \mu \mathrm{m})$ and large-sized diatoms, or by the production of toxins by P. pseudodelicatissimi that prevent it from been grazed by mesozooplankton. Our findings are consistent with an earlier published conceptual model in that (1) the abundance of microzooplankton (ciliates) was high in the near- to mid-field and then decreased toward the far-field, in parallel with phytoplankton stock; (2) mesozooplankton consumed large rather than small prey, thereby affecting the structure of the phytoplankton and microzooplankton community; (3) phytoplankton, dominated by diatoms, were the major food source for mesozooplankton in the plume.
\end{abstract}

KEY WORDS: Mesozooplankton grazing • Diet composition • Microzooplankton • Ciliates · Mississippi River plume

\section{INTRODUCTION}

Phagotrophic protists, including nanoflagellates, dinoflagellates and ciliates, are important nutrient recyclers in the microbial loop. They also form an important trophic link between the microbial loop and the 'classical' grazing food chain, which transfers materials and energy from small cells that are not directly accessible to metazoans such as copepods to higher trophic levels (Sherr et al. 1986, Sherr \& Sherr 1988, Stoecker \& Capuzzo 1990, Gifford 1991, Sanders \& Wickham 1993, Tett \& Wilson 2000).

Copepods are typically the numerically dominant component of the mesozooplankton community, and many studies conducted in the open and coastal ocean indicate they are primarily omnivorous, con- 
suming both heterotrophic and autotrophic prey (e.g. Gifford \& Dagg 1991, Kleppel 1992, Fessenden \& Cowles 1994, Kleppel et al. 1996, Verity \& Paffenhöfer 1996, Nejstgaard et al. 1997, Zeldis et al. 2002, Rollwagen Bollens \& Penry 2003). Microzooplankton can contribute significantly to the diet of mesozooplankton, even when large diatoms are abundant (Stoecker \& Capuzzo 1990, Gifford 1991, Froneman et al. 1996). Experimental studies show that many copepods, e.g. late stages of Calanus spp. and other large calanoids, prefer protozoan prey (Fessenden \& Cowles 1994, Ohman \& Runge 1994, Atkinson 1996), although small copepods appear to be less selective in their feeding (Batten et al. 2001).

Under natural conditions, the contribution of microzooplankton to the mesozooplankton diet varies between zero and close to $100 \%$ (see Table 2 in Kleppel 1992, Table 4 in Halvorsen et al. 2001). This appears mainly dependant on the biological conditions of the study sites, particularly the biomass and size composition of phytoplankton and microzooplankton. For example, Fessenden \& Cowles (1994) found that aloricate phagotrophic ciliates comprised a large portion (16 to $100 \%$ ) of the carbon ingested by copepods during non-upwelling months and between diatom blooms in Oregon coastal waters, whereas the contribution made by ciliates was insignificant during diatom blooms. In general, the contribution of microzooplankton to copepod ingestion is higher where concentrations of microzooplankton are relatively higher and phytoplankton concentrations are lower and dominated by small phytoplankton cells (Kleppel 1992, Batten et al. 2001, Halvorsen et al. 2001).

In the Mississippi River plume, the composition of the food environment for mesozooplankton varies widely over short time and space scales. An idealized description of this system (Dagg \& Breed 2003) suggests that all phytoplankton are stimulated by riverine nutrient inputs but that large cells quickly become dominant because the microzooplankton grazers, which prey more heavily on small cells, can respond more quickly than the mesozooplankton grazers which prey more heavily on large phytoplankton and microzooplankton. Liu \& Dagg (2003) reported patterns in phytoplankton abundance, mesozooplankton abundance, microzooplankton and mesozooplankton grazing that were generally consistent with the conceptual model of Dagg \& Breed (2003); however, microzooplankton abundance and species composition were not examined, nor was mesozooplankton grazing on microzooplankton. Here we provide additional information from these same experiments on microzooplankton abundance and distribution, and on mesozooplankton feeding on microzooplankton.

\section{MATERIALS AND METHODS}

In March 2002, we conducted 5 shipboard grazing experiments spanning locations from near the largest discharge point of the Mississippi River (near-field, Stn 1) to a high-salinity location approximately $60 \mathrm{~km}$ to the SW (far-field, Stn 5) (Fig. 1).

Prior to the cruise and between each experiment, all experimental bottles, tubing and other containers were cleaned with $10 \% \mathrm{HCl}$, followed by a thorough rinse with distilled water. Seawater for experiments was collected from the surface with Niskin bottles, and gently transferred to a large polycarbonate carboy through tubing with a $202 \mu \mathrm{m}$ mesh at one end. This wellmixed seawater was then used to fill a set of 2.41 polycarbonate incubation bottles.

Mesozooplankton were collected from the plume (either the upper 10 or $5 \mathrm{~m}$ ) using a plankton net with mesh size of $202 \mu \mathrm{m}$. The cod-end of the net was taped to minimize damage caused by friction between organisms and mesh. Contents of the cod-end were carefully poured into an insulated container, and only freeswimming organisms $<2000 \mu \mathrm{m}$ were used for experiments. Animals > $2000 \mu \mathrm{m}$ were excluded by immersing a sieve made of $2000 \mu \mathrm{m}$ mesh in the container. Aliquots of mesozooplankton were placed into duplicate bottles filled with $202 \mu \mathrm{m}$ pre-screened seawater and incubated for $24 \mathrm{~h}$, together with a pair of control bottles with no mesozooplankton. To prevent the possibility of differential phytoplankton growth in the control and treatment bottles resulting from zooplankton excretion, a nutrient mixture $(10 \mu \mathrm{M}$ N, $10 \mu \mathrm{M}$ Si and $1 \mu \mathrm{M}$ P, final conc.) was added to each bottle.

Duplicate aliquots of mesozooplankton were collected on pre-weighed $20 \mu \mathrm{m}$ polycarbonate filters

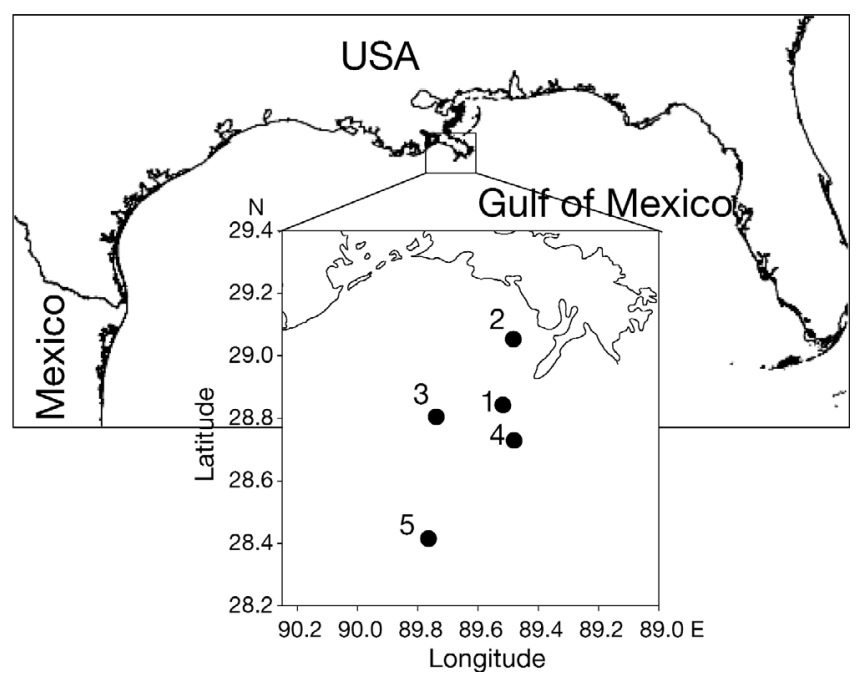

Fig. 1. Station locations. Stn 1: near-field; Stns 3-4; mid-field; Stn 5: far-field; Stn 2; not considered to be in river plume 
and dried in a $60^{\circ} \mathrm{C}$ oven for determination of the mesozooplankton dry weight added to experimental bottles. A portion of the initial net tow was also processed to estimate the total dry weight. The rest of the net tow sample was collected on a sieve, transferred to a $500 \mathrm{ml}$ plastic bottle, and preserved with $10 \%$ buffered formalin for future identification and enumeration.

All experimental bottles were tightly capped after filling, bagged with 1 layer of neutral screen, and placed in on-deck incubators for $24 \mathrm{~h}$ with temperature controlled by running surface seawater. Samples were taken at the beginning and end of the experiment for size-fractionated chlorophyll a concentrations in 3 size classes $(<5,5$ to 20 and $>20 \mu \mathrm{m}$; Liu \& Dagg 2003) and for determination of microzooplankton abundance.

For microplankton enumeration, $100 \mathrm{ml}$ from each bottle were preserved with $5 \%$ acid Lugol's solution. In the laboratory, subsamples of 10 to $50 \mathrm{ml}$ were placed in sedimentation chambers to settle for 12 to $24 \mathrm{~h}$ (Utermöhl 1958). Microplankton cells including diatoms, dinoflagellates, aloricate ciliates, Mesodinium rubrum and tintinnids were identified and counted with an inverted microscope (Nikon-TMD 300) at 200 or $400 \times$ magnification. Ciliates were assumed to be standard geometric forms (Ota \& Taniguchi 2003) and at least 30 cells of each species were measured. Cell biomass was calculated using a volume-to-carbon con-

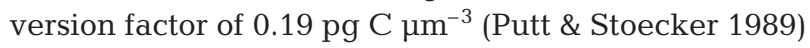
for oligotrich ciliates and M. rubrum and $444.5+0.053$ lorica volume $\left(\mu^{-3}\right) \mathrm{pg} \mathrm{C}$ for tintinnids (Verity \& Langdon 1984).

A data matrix was constructed to allow comparison of mesozooplankton populations between stations. Comparisons were based on percent composition at each station, not on absolute concentrations. Cluster analysis was performed on the data matrix with a single linkage method using the arithmetical nearestneighbor distance to organize the stations into different types (Pielou 1984).

Mesozooplankton clearance rates $(F)$ were calculated following the formulae of Frost (1972):

$$
F\left(\mathrm{lmg}^{-1} \text { dry wt d }{ }^{-1}\right)=V\left(k_{\mathrm{c}}-k_{\mathrm{t}}\right) / Z
$$

where $V$ is the volume (l) of the incubation bottle and $Z$ is mesozooplankton biomass (mg dry wt) added to the incubation bottles, $k_{\mathrm{c}}$ and $k_{\mathrm{t}}$ are the net or apparent prey growth rates in the controls and treatments $\left(\mathrm{d}^{-1}\right)$, respectively, which are calculated by:

$$
k\left(\mathrm{~d}^{-1}\right)=\ln \left(C_{\mathrm{e}} / C_{0}\right)
$$

for $24 \mathrm{~h}$ incubation, where $C_{0}$ is the concentration of prey in the initial bottles, and $C_{\mathrm{e}}$ is the concentration of prey in the control and treatment bottles at the end of the incubation.
Ingestion rate $(I)$ is calculated by:

$$
I\left(\mu \mathrm{C} \mathrm{mg}^{-1} \text { dry wt d } \mathrm{d}^{-1}\right)=C F
$$

where $C$ is the mean concentration of prey throughout the $24 \mathrm{~h}$ incubation period calculated by:

$$
C=C_{0}\left(\mathrm{e}^{k_{\mathrm{t}}}-1\right) / k_{\mathrm{t}}
$$

\section{RESULTS}

\section{Plankton community structure}

Based on physical and biological properties, Liu \& Dagg (2003) placed each station within the continuum of conditions between river discharge and the open Gulf of Mexico, as described in the conceptual model of Dagg \& Breed (2003). Thus, Stn 1 was characterized as a near-field station, Stns 3 and 4 were mid-field stations and Stn 5 was a far-field station. Stn 2 , located in a shallow $(\sim 10 \mathrm{~m})$ back-stream area where considerably older river water often accumulates (Wiseman et al. 1982), was not considered to be in the river plume.

Chlorophyll a concentration at the experimental sites in the plume ranged from 4.3 to $5.6 \mathrm{mg} \mathrm{m}^{-3}$, and was dominated by phytoplankton cells in the $>20 \mu \mathrm{m}$ and/or 5 to $20 \mu \mathrm{m}$ size fractions (Liu \& Dagg 2003). The high chlorophyll a concentrations and dominance of large phytoplankton indicate that none of our stations were located in true far-field or oligotrophic oceanic waters. Diatoms were the most abundant microphytoplankton at all sites, ranging from $3.6 \times 10^{5}$ cells $1^{-1}$ at near-field Stn 1 to $1.8 \times 10^{7}$ cells $1^{-1}$ at mid-field Stn 3 (Table 1). Diatom abundance remained high at the farfield plume station (Stn 5). In spite of large differences in diatom abundance, the dominant species were strikingly similar (Table 2). Pseudonitzschia pseudodelicatissima was the dominant species at all experimental sites, especially at mid-shelf stations where it accounted for more than $90 \%$ of total diatom numbers. Concentrations of both dinoflagellates and ciliates decreased from near- to far-field stations, in contrast to

Table 1. Microplankton abundance at each experimental site

\begin{tabular}{|crrrr|}
\hline Site & \multicolumn{4}{c|}{ Microplankton abundance $\left(10^{3}\right.$ cells l $\left.^{-1}\right)$} \\
& Ciliates & $\begin{array}{c}\text { Mesodinium } \\
\text { rubrum }\end{array}$ & Dinoflagellates & Diatoms \\
\hline & 13.5 & 46.5 & 312.8 & 357 \\
1 & 30.0 & 87.0 & 464.6 & 719 \\
2 & 6.2 & 6.8 & 141.2 & 17660 \\
3 & 8.5 & 11.0 & 71.5 & 4156 \\
4 & 3.2 & 3.3 & 44.0 & 2309 \\
5 & & & & \\
\hline
\end{tabular}




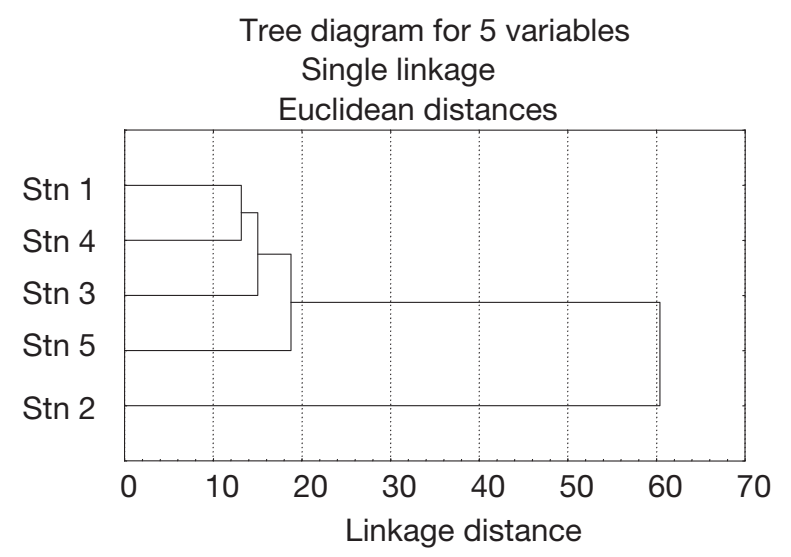

Fig. 2. Mesozooplankton composition at 5 experimental stations. Cluster analysis on data matrix of composition proportion of each species using single-linkage method based on arithmetical nearest neighbor distance

diatoms, which peaked in the mid-field region. Dinoflagellates were dominated by prorocentroid, gymnodinoid and peridinoid forms. Gonyaulacoid and dinophysoid species were rare at all sites. Ciliates were mainly composed of Lohmanniella ovifomis, Tontonia sp., Strombidium spp., as well as Mesodinium rubrum. Tintinnid abundance was low at all stations. There were more $M$. rubrum than oligotrich ciliates in the near-field, and the contribution of this species to total ciliate abundance decreased toward the far-field. The ratio of $M$. rubrum to oligotrich ciliates decreased from 3.5 at Stn 1 to 0.4 at Stn 5. Within oligotrich ciliates, small heterotrophic L. oviforms predominated in the near-field (Stn 1), whereas large mixotrophic Tontonia sp. was the most abundant species at the mid-field stations. In the far-field, L. oviforms again predominated (Table 2).

Mesozooplankton biomass in the upper water column varied widely (Liu \& Dagg 2003). Grouping analysis of mesozooplankton composition (Fig. 2) did not separate the stations as distinctly as other water properties. Stns 1 and 4, located on the 2 sides of a strong frontal zone where intensive mixing occurred between river discharge and receiving oceanic water, were most closely related. Stns 3 and 5 were also closely related to Stns 1 and 4. Only Stn 2 was distinctively distanced from all other stations. Stn 2 located in the shallow coastal water north of the river mouth, is unique in several aspects. It has the highest chlorophyll a concentration $\left(10 \mathrm{mg} \mathrm{m}^{-3}\right)$, highest abundances of dinoflagellates (dominated by prorocentroid forms) and ciliates (mostly Mesodinium rubrum), and lowest mesozooplankton biomass (2.8 mg dry wt $\mathrm{m}^{-3}, 87 \%$ Acartia tonsa) (Tables 1 \& 2, and Liu \& Dagg 2003).

\section{Mesozooplankton grazing on ciliates, diatoms and dinoflagellates}

At near-field Stn 1, mesozooplankton clearance rate was similar on diatoms, dinoflagellates, oligotrich ciliates and Mesodinium rubrum ciliates (Fig. 3). At Stn 2, clearance rate on $M$. rubrum was more than 2 times higher than the rates on oligotrich ciliates, dinoflagellates and diatoms (ANOVA, $\mathrm{p}<0.05)$. The most important feature for Stn 3, where the diatom Pseudonitzschia pseudodelicatissima bloomed, was the significantly lower clearance rate observed on diatoms (ANOVA, p < 0.01). Mesozooplankton clearance rate on diatoms was still significantly lower than on other prey items at Stns 4 and 5 (ANOVA, p < 0.05), except for $M$. rubrum at Stn 5, where its abundance was very low.

Ingestion of ciliate carbon by mesozooplankton ( $\mu \mathrm{g}$

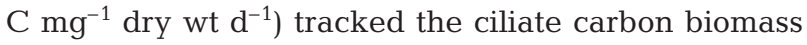
(Table 3). Ingestion declined from its maximum in the near-field, to intermediate levels at the mid-field stations to the lowest observed rate at the far-field station (Table 3). Ingestion rate was much higher at Stn 2 than at any of the plume stations, although mesozooplankton abundance was lowest there. Among ciliates in the diet, mesozooplankton ingested more carbon from oligotrichs than from Mesodinium rubrum, except at Stn 2, where mesozooplankton ingestion of $M$. rubrum was nearly 3 times more than that of oligotrich ciliates (Table 3). The high ingestion rate of $M$. rubrum at Stn $2\left(141 \mu \mathrm{g} \mathrm{C} \mathrm{mg}^{-1}\right.$ dry wt d ${ }^{-1}$ ) was the result of a combination of high abundance of $M$. rubrum (Table 1) and high clearance rate of mesozooplankton on $M$. rubrum (Fig. 3).

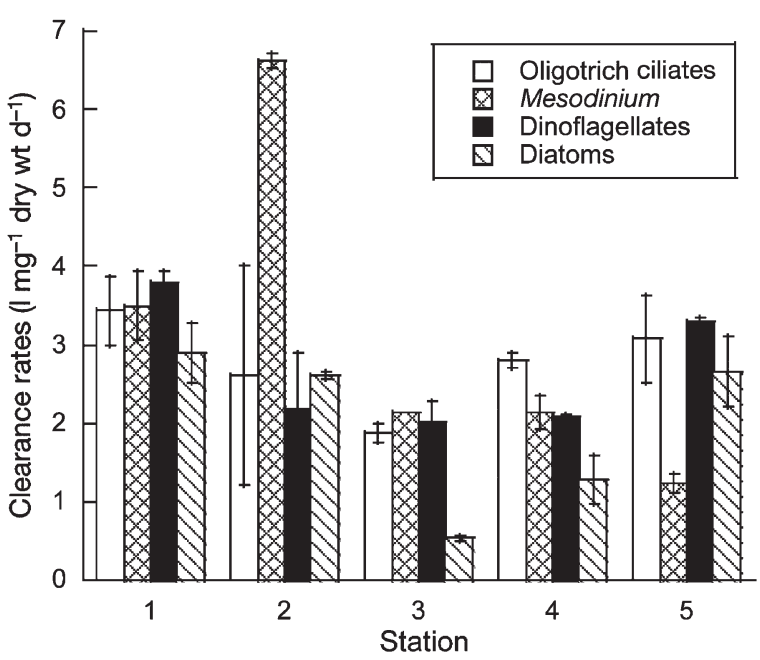

Fig. 3. Mean $( \pm \mathrm{SE}, \mathrm{n}=2$ replicates $)$ mesozooplankton clearance rates on oligotrich ciliates, Mesodinium rubrum, dinoflagellates and diatoms 
Table 2. Dominant species (groups) of oligotrich ciliates, dinoflagellates, diatoms and mesozooplankton at each experimental station. Species (groups) that accounted for more than $5 \%$ of total abundance are listed with their percentage of total abundance in parentheses

\begin{tabular}{|c|c|c|c|c|}
\hline Stn & Oligotrich ciliates & Dinoflagellates & Diatoms & Mesozooplankton \\
\hline \multirow[t]{3}{*}{1} & Lohmanniella ovifomis (47.9) & Peridinoid (42.5) & $\begin{array}{l}\text { Pseudonitzschia } \\
\text { pseudodilicatissima (72.9) }\end{array}$ & Acartia tonsa (30.6) \\
\hline & Tontonia sp. (25.7) & Prorocentroid (35.5) & Navicula distans (14.6) & Paracalanus spp. (26.3) \\
\hline & Strombidium spp. (23.5) & Gymnodinoid (21.6) & & Doliolids (5.6) \\
\hline \multirow[t]{3}{*}{2} & L. ovifomis (40.0) & Prorocentroid (81.6) & P. pseudodilicatissima (95) & A. tonsa $(87.4)$ \\
\hline & Tontonia sp. (36.0) & Peridinoid (11.8) & & P. crassirostris (8.0) \\
\hline & Strombidium spp. (18.7) & Gymnodinoid (6.2) & & \\
\hline \multirow[t]{5}{*}{3} & Tontonia sp. (44.4) & Prorocentroid (68.2) & P. pseudodilicatissima (96) & A. tonsa (31.3) \\
\hline & L. ovifomis (23.8) & Gymnodinoid (20.0) & & Paracalanus spp. (19.5) \\
\hline & Strombidium spp. (15.9) & Peridinoid (11.2) & & P. crassirostris (13.5) \\
\hline & Leegaardiella sol (9.5) & & & Larvacean $(7.0)$ \\
\hline & Strombilidium sprialis (6.3) & & & \\
\hline \multirow[t]{6}{*}{4} & Tontonia sp. (37.0) & Prorocentroid (43.8) & P. pseudodilicatissima (93) & A. tonsa $(23.0)$ \\
\hline & Strombidium spp. (31.5) & Gymnodinoid (30.4) & & Paracalanus spp. (19.7) \\
\hline & L. ovifomis (27.8) & Peridinoid (24.6) & & Doliolids (9.6) \\
\hline & & & & P. crassirostris $(6.6)$ \\
\hline & & & & Larvacean (5.2) \\
\hline & & & & Nauplii (5.2) \\
\hline \multirow[t]{4}{*}{5} & L. ovifomis (66.2) & Prorocentroid (77.7) & P. pseudodilicatissima (86.3) & Doliolids (18.6) \\
\hline & Strombidium spp. (22.1) & Gymnodinoid (13.3) & & Paracalanus spp. (17.5) \\
\hline & Tontonia sp. (8.3) & Peridinoid (8.5) & & Acartia tonsa (13.2) \\
\hline & & & & Oncaea spp. (12.0) \\
\hline
\end{tabular}

\section{Ciliate size and mesozooplankton feeding}

We binned ciliates into $5 \mu \mathrm{m}$ intervals based on ESD. In all, ciliates were dominated by cells smaller than $20 \mu \mathrm{m}$ ESD but show a marked difference in size composition among experimental sites (Fig. 4). After incubation, abundance of ciliates increased in the control bottles although the size spectrum was also changed in some experiments. Ciliate abundances decreased dramatically in the bottles with mesozooplankton added, with ciliates $>30 \mu \mathrm{m}$ ESD virtually disappearing from the treatment bottles of all experiments (Fig. 4).

While small ciliates were the most numerically abundant, large ciliates were important in terms of carbon biomass, and at some stations their biomass was as high as the biomass of the small ciliates (Fig. 5). In Stns 1 and 2, ciliates in the size range 16 to $20 \mu \mathrm{m}$ ESD contributed the most to carbon biomass. In Stn 3, a bimodal biomass distribution was apparent, with peaks at 16 to 20 and 41 to $45 \mu \mathrm{m}$. In Stn 4 , larger (26 to $30 \mu \mathrm{m}$ ESD) ciliates provided the most biomass, and in Stn 5 both small (5 to $15 \mu \mathrm{m}$ ESD) and large (26 to $35 \mu \mathrm{m}$ ESD) were equally important. The right-hand panels in Fig. 5 shows the importance of large ciliates in term of mesozooplankton carbon ingestion.

Because of the low number of large ciliates, we pooled cells $>30 \mu \mathrm{m}$ to calculate clearance and ingestion rates. Mesozooplankton clearance on differentsized ciliates displayed 2 different patterns (Fig. 6, Table 4). At Stns 1 and 5, clearance rates were highest

Table 3. Initial carbon biomass and mesozooplankton ingestion of Mesodinium rubrum, oligotrich, tintinnid and total ciliates in each experiment. Ingestion rates of tintinnids were calculated using clearance rates of oligotrichs because low tintinnid abundance prevented accurate measurement of clearance rates

\begin{tabular}{|c|c|c|c|c|c|c|c|c|}
\hline \multirow{2}{*}{ Stn } & \multicolumn{4}{|c|}{ Carbon biomass $\left(\mu g \mathrm{C}^{-1}\right)$} & \multicolumn{4}{|c|}{ Ingestion $\left(\mu \mathrm{g} \mathrm{C} \mathrm{mg}^{-1}\right.$ dry wt $\left.\mathrm{d}^{-1}\right)$} \\
\hline & M. rubrum & Oligotrichs & Tintinnids & Total & M. rubrum & Oligotrichs & Tintinnids & Total \\
\hline 1 & 10.45 & 12.78 & 0.04 & 23.23 & 16.89 & 17.36 & 0.16 & 34.41 \\
\hline 2 & 38.55 & 23.86 & 0.43 & 62.84 & 140.78 & 48.88 & 0.48 & 190.13 \\
\hline 3 & 1.88 & 8.00 & 0.14 & 10.02 & 2.66 & 11.05 & 0.10 & 13.81 \\
\hline 4 & 1.91 & 8.58 & 0.35 & 10.84 & 1.77 & 10.27 & 0.42 & 12.47 \\
\hline 5 & 0.56 & 1.25 & 0.19 & 2.00 & 0.57 & 3.95 & 0.30 & 4.82 \\
\hline
\end{tabular}



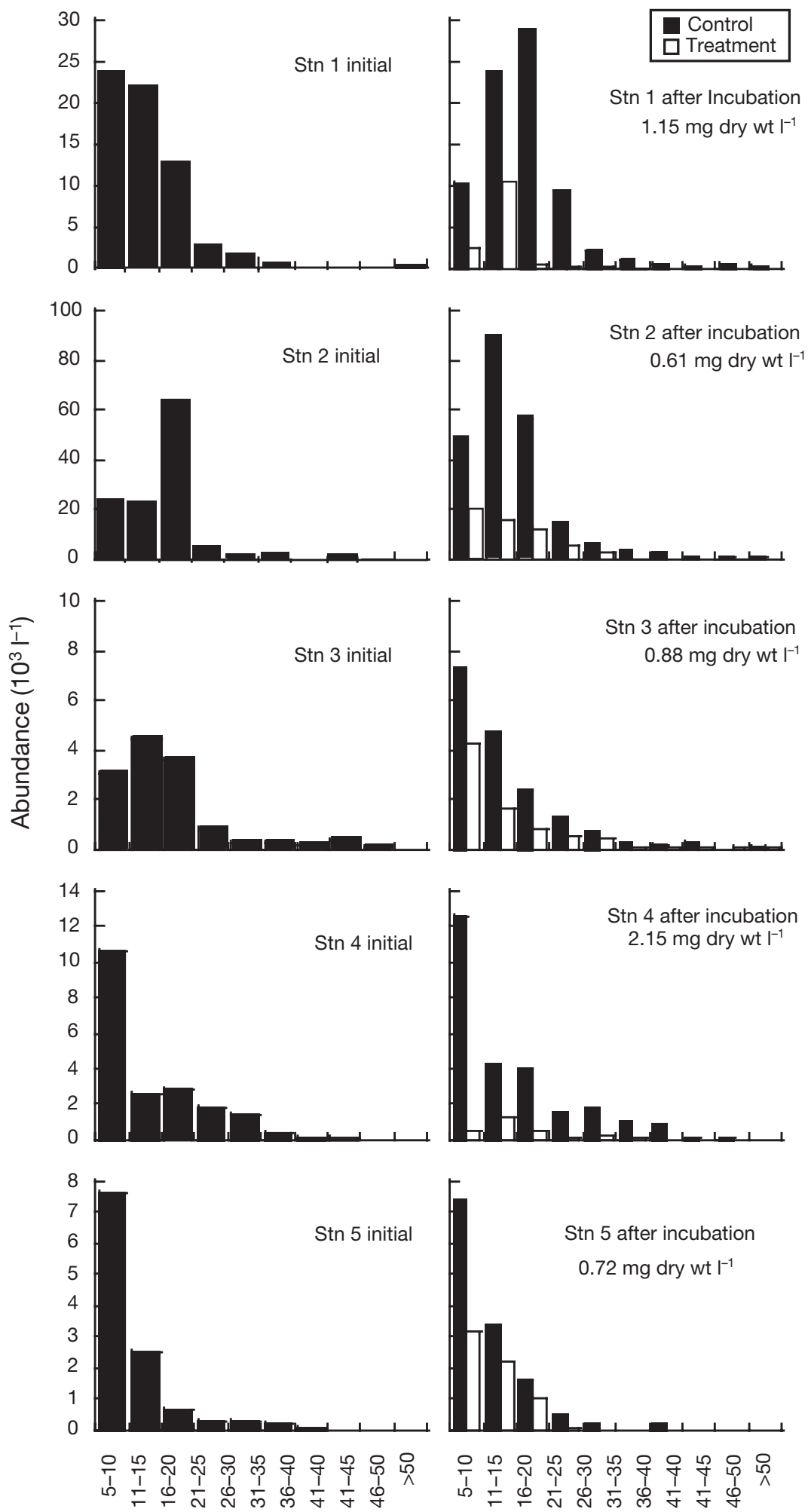

Size $(\mu \mathrm{m}$ ESD)

Fig. 4. Size distribution of ciliate abundance before and after incubation in 5 mesozooplankton experiments at 5 stations in the Mississippi River plume during March 2002. The amounts of mesozooplankton added to 'Treatment' bottles are shown in the right-hand panels 

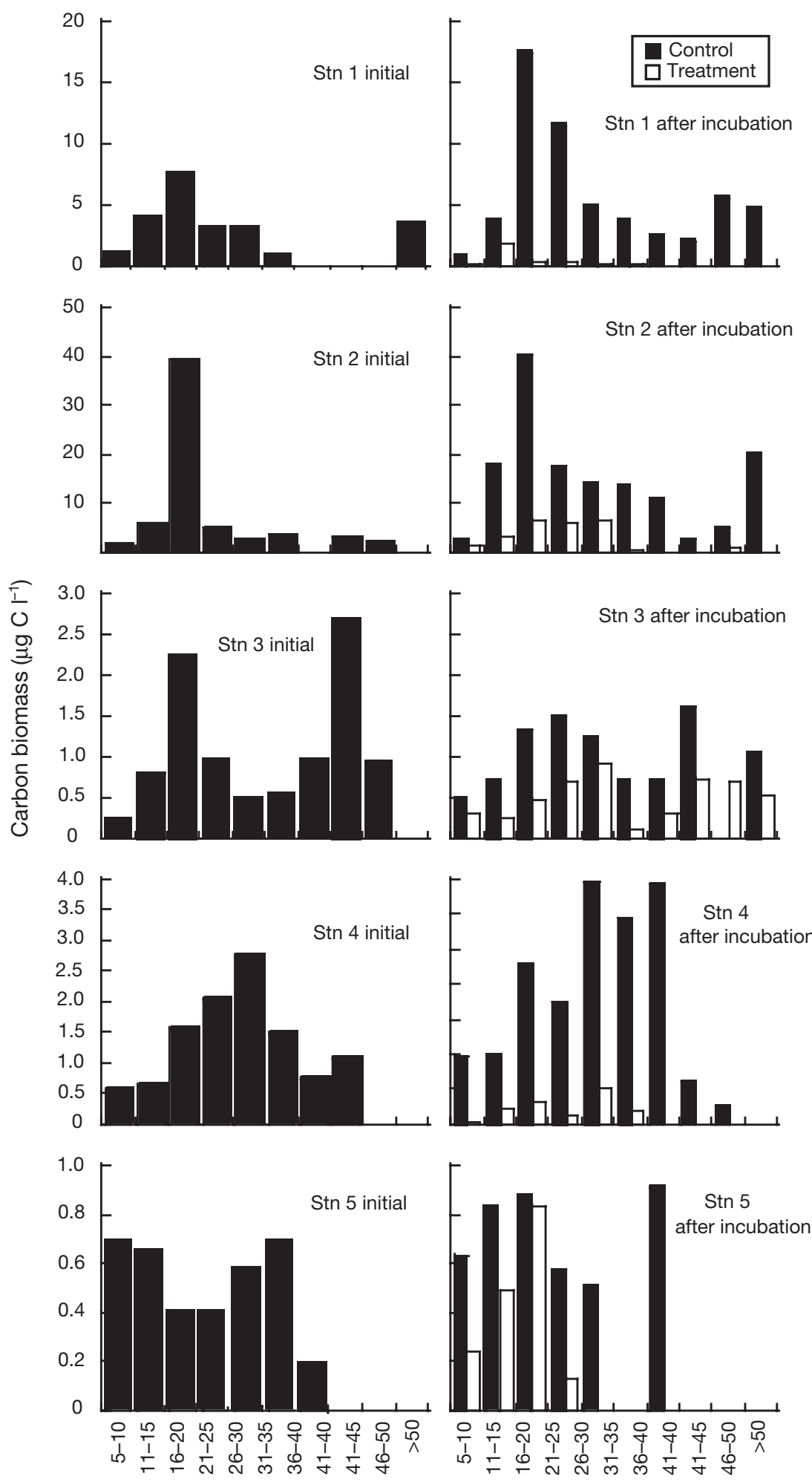

Size ( $\mu \mathrm{m}$ ESD)

Fig. 5. Size distribution of ciliate carbon biomass before and after incubation in 5 mesozooplankton experiments at 5 stations. Further details as in Fig. 4 
Table 4. Mesozooplankton clearance and ingestion rates on ciliates $<20$ and $>20 \mu \mathrm{m}$ ESD (including oligotrichs, Mesodinium rubrum and tintinnids)

\begin{tabular}{|c|c|c|c|c|}
\hline \multirow[t]{2}{*}{ Stn } & \multicolumn{2}{|c|}{$\begin{array}{l}\text { Clearance rates } \\
\left(\mathrm{mg}^{-1} \text { dry wt d }^{-1}\right)\end{array}$} & \multicolumn{2}{|c|}{$\begin{array}{c}\text { Ingestion rates } \\
\left(\mu \mathrm{C} \mathrm{mg}^{-1} \text { dry wt }^{-1}\right)\end{array}$} \\
\hline & $<20 \mu \mathrm{m}$ & $>20 \mu \mathrm{m}$ & $<20 \mu \mathrm{m}$ & $>20 \mu \mathrm{m}$ \\
\hline 1 & 3.07 & 7.37 & 24.69 & 30.60 \\
\hline 2 & 5.37 & 4.86 & 156.22 & 87.42 \\
\hline 3 & 2.04 & 2.03 & 5.18 & 9.75 \\
\hline 4 & 2.45 & 2.89 & 3.00 & 9.62 \\
\hline 5 & 2.20 & 7.32 & 2.91 & 5.34 \\
\hline
\end{tabular}

on large ciliates. At the intermediate stations, mesozooplankton clearance rates were more uniform on ciliates of all sizes. For ingestion, the highest rates were usually found in the size ranges corresponding to the highest in situ carbon biomass.

Mesozooplankton ingested more carbon from $>20 \mu \mathrm{m}$ ciliates than from $<20 \mu \mathrm{m}$ ciliates at all sites, except at Stn 2 where mesozooplankton ingested 2.6 times more carbon from small ciliates than from large ciliates (Table 4). The high contribution of small ciliates at Stn 2 was a result of high abundance of $M$. rubrum, which have an ESD of $<20 \mu \mathrm{m}$.

\section{DISCUSSION}

\section{Methodology}

Our approach to measuring mesozooplankton grazing provides a simple way to assess the community rate but does not provide detailed information on which mesozooplankton species are most important as grazers. However, our estimates of mesozooplankton community grazing rates must still be considered conservative because gelatinous zooplankton were excluded from our experiments. Gelatinous microphages, including larvaceans, salps and doliolids, are able to feed on a wide size range of particles, including bacteria (Flood et al. 1992, Fortier et al. 1994). While these organisms are generally rare in the near-field of the plume, they can be very abundant in the mid- and farfield waters (present Table 2 and R. Sato et al. unpubl.) and previous studies have indicated they can filter a significant portion of the surface water and consume large portions of daily algal production (Dagg 1995, Dagg et al. 1996). Therefore, separate experiments measuring the feeding rates of gelatinous microphages must be conducted to obtain a more accurate estimate of total mesozooplankton grazing.

\section{Importance of ciliate size}

Ciliates contributed to the mesozooplankton diet at all stations. Large species were cleared at equal or higher rates than smaller species, although small-sized $(<20 \mu \mathrm{m}$ ESD) ciliates were by far the most abundant. The pattern of higher clearance rates on larger-sized prey has been shown in many copepod species (Paffenhöfer 1988). For example, the clearance rate of Acartia tonsa and Paracalanus parvus increased monotonically as a function of algal radius in natural multialgal suspensions of low concentration until a high-end size-cutoff. (Bartram 1981). Berggreen et al. (1988) found that
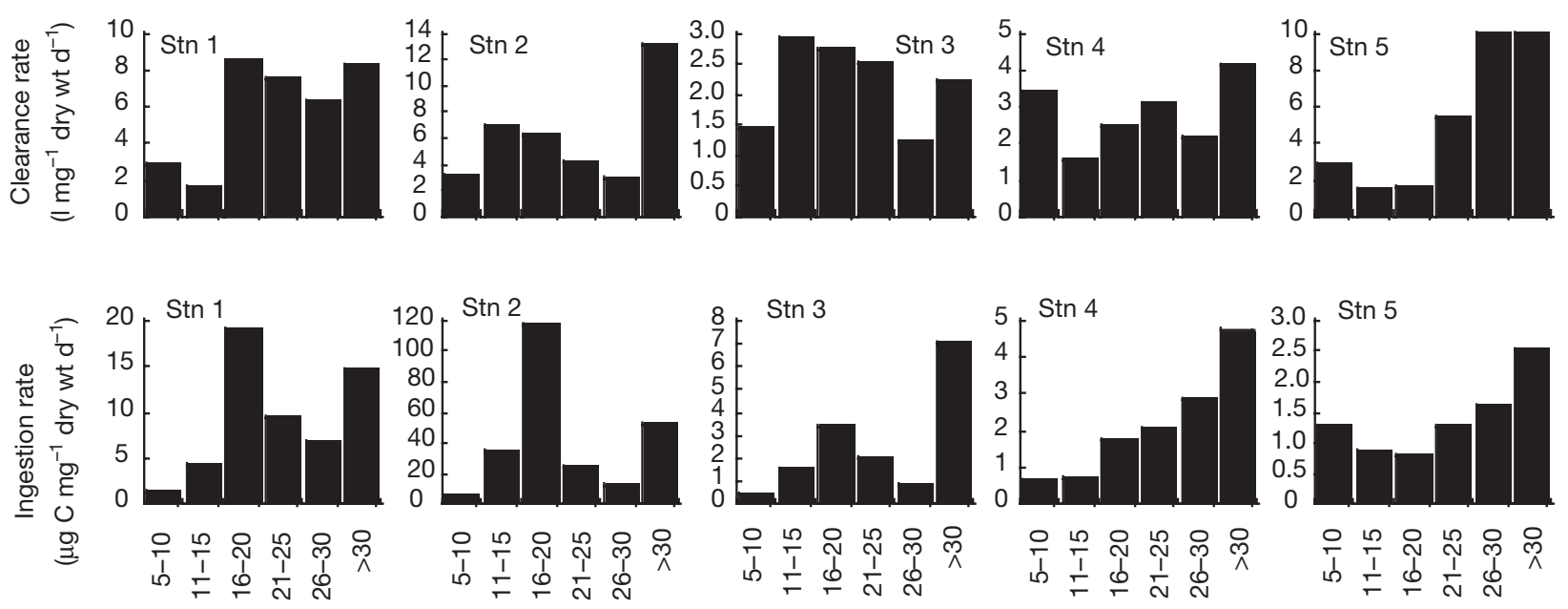

Size ( $\mu \mathrm{m}$ ESD)

Fig. 6. Size-specific mesozooplankton clearance rates (top panels) and ingestion rates (bottom panels) of ciliates at 5 stations in the Mississippi River plume. Data are means of duplicate samples 
the optimum particle size for adult $A$. tonsa was 14 to $70 \mu \mathrm{m}$. A. tonsa and A. clausi both demonstrated selective feeding on large cells from natural suspensions of Chesapeake Bay plankton (Richman et al. 1977). Similarly, A. tonsa preferred prey cells $>15 \mu \mathrm{m}$ in size and did not ingest cells $<10 \mu \mathrm{m}$ in San Francisco Bay (Rollwagen Bollens \& Penry 2003). Increased selectivity for large prey by suspension-feeding mesozooplankton is probably due to their easier detection and capture compared to smaller cells (Jonsson \& Tiselius 1990), especially in particle-rich environments (Stoecker \& Egloff 1987) such as the Mississippi River plume. The size of ciliates in our experimental sites falls within the optimum prey-particle size of Acartia spp. and other smallto mid-sized copepods. In our study, mesozooplankton displayed higher clearance rates on large ciliates than on small ciliates in some experiments, whereas in other experiments the clearance rates on large and small ciliates were the same (Table 4). Such differences in mesozooplankton feeding behavior, i.e. prey size-dependent vesus prey size-independent, may be explained by a difference in mesozooplankton composition. Different copepod species have different feeding behaviors and the composition of the mesozooplankton community will affect feeding on natural prey assemblages. For example, mesozooplankton at our shallow Stn 2 was $87 \%$ A. tonsa, whereas at $\mathrm{Stn} 5$ A. tonsa represented only $13 \%$ of the total mesozooplankton; therefore the attributes of $A$. tonsa will be more important at Stn 2. However, copepod ingestion in natural prey assemblages is affected by many other factors including the density, size, behavior, nutritional quality and physiological status of the prey and the physical environmental conditions. These factors may have contributed to some of the variability in clearance rate observed in our experiments.

\section{Importance of microzooplankton in mesozooplankton diet}

Table 5 shows 2 estimates of total mesozooplankton ingestion of ciliates. The first is the sum of oligotrich ciliates, tintinnids and Mesodinium rubrum obtained from Table 3, the second the sum of the products of size-specific clearance rates and size-specific biomass (Figs. $5 \& 6$ ). The second estimate is consistently, although not significantly, higher than the first, particularly for Stns 1, 2 and 5 in which larger ciliates were cleared at much higher rates than smaller ciliates. Since large cells can be very important to dietary carbon, the second estimate may be a better simulation of in situ conditions.

Using phytoplankton growth and mesozooplankton grazing rates reported in Liu \& Dagg (2003), we calculated mesozooplankton consumption of chlorophyll (chl) $a$ and converted it to carbon biomass using a C:chl ratio of 50 (Table 5). Compared to the contribution of phytoplankton carbon, the contribution of oligotrich ciliates to total mesozooplankton carbon ingestion increased from near-field Stn 1 (5.3 to $11.0 \%$ ) to a maximum at mid-field Stn 3 (30.0 to $38.4 \%$ ), and decreased toward far-field Stn 5 (0.9 to $1.7 \%)$ (Table 5). The C:chl ratio of 50 (Banse 1977) is widely used for estuarine waters (e.g. Vincent \& Hartmann 2001). However, it is possible that the mesozooplankton ingestion of phytoplankton carbon was overestimated in the near-field stations and underestimated in the far-field station because the C:chl ratio may increase significantly from the near-field to the farfield of the plume (Lohrenz et al. 1992, Chang et al. 2003). Nevertheless, the maximum contribution of oligotrich ciliates to the mesozooplankton diet clearly occurred in the mid-field.

Table 5. Estimates of mesozooplankton ingestion rates on ciliates and phytoplankton and contribution of ciliates to mesozooplankton diet

\begin{tabular}{|c|c|c|c|c|c|c|c|}
\hline \multirow[t]{2}{*}{ Stn } & \multicolumn{2}{|c|}{$\begin{array}{l}\text { Ingestion of total ciliates } \\
\left(\mu \mathrm{g} \mathrm{C} \mathrm{mg}^{-1} \text { dry wt } \mathrm{d}^{-1}\right)\end{array}$} & \multicolumn{3}{|c|}{$\begin{array}{l}\text { In situ ingestion } \\
\left(\mathrm{mg} \mathrm{C} \mathrm{m}^{-3} \mathrm{~d}^{-1}\right)\end{array}$} & \multicolumn{2}{|c|}{$\%$ ciliate to total carbon ingestion } \\
\hline & Rate estimate $1^{\mathrm{a}}$ & Rate estimate $2^{\mathrm{b}}$ & Phytoplankton ${ }^{\mathrm{c}}$ & Total ciliates ${ }^{d}$ & $\begin{array}{l}\text { Excluding } \\
\text { Mesodinium }^{\text {rubrum }} \\
\text { rubrum }^{\text {d }}\end{array}$ & Total ciliates $^{\mathrm{d}}$ & $\begin{array}{l}\text { Excluding } \\
\text { Mesodinium }^{\text {rubrum }}{ }^{\mathrm{d}}\end{array}$ \\
\hline 1 & 34.41 & 55.29 & 25.96 & $2.87-4.61$ & $1.46-3.20$ & $9.9-15.1$ & $5.3-11.0$ \\
\hline 2 & 190.13 & 243.65 & 0.73 & $0.53-0.68$ & $0.14-0.29$ & $42.2-48.4$ & $16.0-28.3$ \\
\hline 3 & 13.81 & 14.93 & 0.33 & $0.23-0.25$ & $0.19-0.20$ & $34.7-43.1$ & $30.0-38.4$ \\
\hline 4 & 12.47 & 12.62 & 29.01 & $1.31-1.32$ & $1.12-1.14$ & $4.3-4.4$ & $3.7-3.8$ \\
\hline 5 & 4.82 & 8.26 & 26.21 & $0.28-0.47$ & $0.24-0.44$ & $1.0-1.8$ & $0.9-1.7$ \\
\hline \multicolumn{8}{|c|}{ 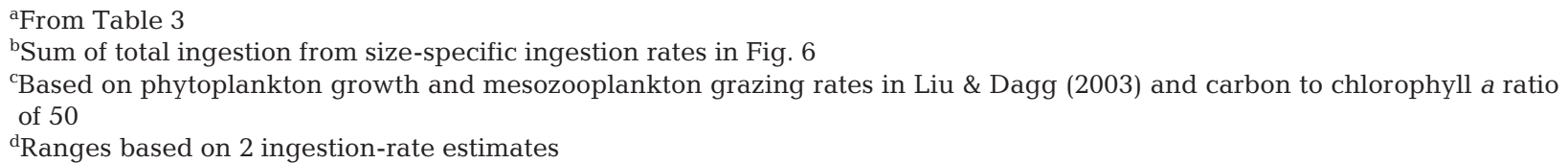 } \\
\hline
\end{tabular}


Based on these estimates (Table 5), it is clear that phytoplankton was more important as a food source than ciliates at all stations, although only slightly so at Stns 2 and 3. At Stn 2 (not in the plume) mesozooplankton biomass was extremely low and was composed almost entirely of Acartia tonsa. The autotrophic ciliate Mesodinium rubrum, was very abundant, contributing significantly to mesozooplankton carbon ingestion. At Stn 3 there was a very high concentration of the diatom Pseudonitzschia pseudodelicatissima, and mesozooplankton grazing on phytoplankton, particularly on diatoms, was very low (Table 5, and Liu \& Dagg 2003) Mesozooplankton biomass was also low at this station. We do not know whether low mesozooplankton biomass and grazing activity is a result of any toxins produced by $P$. pseudodelicatissima. We observed that at the near-field station, diatoms were cleared at the same rate as other prey, but at Stn 3, where P. pseudodelicatissima was very abundant (17000 cells $\left.\mathrm{ml}^{-1}\right)$, low mesozooplankton grazing on diatoms was observed. At Stns 4 and 5, P. pseudodelicatissima abundances were lower, although still greater than near-field Stn 1, and clearance rate remained low. These findings suggest that mesozooplankton in the plume, dominated by A. tonsa and other small copepods, cannot efficiently feed on $P$. pseudodelicatissima which is usually $>100 \mu \mathrm{m}$ long, especially when it is found at very high concentrations. Mesozooplankton may also actively avoid feeding on $P$. pseudodelicatissima, which is reported to be able to produce toxic domoic acid (Martin et al. 1990, Pan et al. 2001). The development stage of the bloom could also be a factor since domoic acid content and production rate of $P$. pseudodelicatissima differ during different growth phases (Pan et al. 2001).

An interesting finding is that the contribution of ciliates to mesozooplankton carbon ingestion was highest at Stn 3 where, in spite of a diatom bloom, phytoplankton contribution to mesozooplankton diet was very low. This does not agree with the general pattern, which suggests that a high microzooplankton contribution to the mesozooplankton diet occurs when phytoplankton abundances are low (Kleppel 1992, Fessenden \& Cowles 1994, Halvorsen et al. 2001). It also has been suggested that blooms of phytoplankton may provide survival windows for ciliates because of reduced predation pressure from copepods (Kiørboe et al. 1996, Kiørboe 1998). Our results do not support this hypothesis. Instead, our results suggest that mesozooplankton may be able to selectively ingest microzooplankton over unfavorable or harmful diatom species such as Pseudonitzschia pseudodelicatissima.

The data in Table 5 only show the contribution of ciliate carbon to total mesozooplankton ingestion. Since we were not able to separate autotrophic and hetero- trophic dinoflagellates in samples fixed with Lugol's solution, we were not able to estimate their contribution to total mesozooplankton carbon ingestion. According to Strom \& Strom (1996), microzooplankton biomass in general was approximately equally divided between ciliates and dinoflagellates in the Mississippi River plume. If we assume that the biomass of heterotrophic dinoflagellates is approximately equal to those of heterotrophic and mixotrophic ciliates at our study sites, our conclusion would be that the microzooplankton contribution to mesozooplankton diet would range between a maximum of more than $60 \%$ at Stn 3 and a minimum of only $2 \%$ at $\operatorname{Stn} 5$.

\section{Planktonic community structure in the plume}

The Mississippi River is one of the world's 10 largest rivers. Discharge of freshwater and its dissolved and particulate constituents affect broad areas of the northern Gulf of Mexico (Ortner \& Dagg 1995). According to the conceptual model of Dagg \& Breed (2003), conditions for phytoplankton growth in the lower river are poor because of high concentrations of suspended sediments, but immediately after discharge and formation of a surface plume, the settling of large lithogenic particles results in a greatly improved light environment. Combined with high concentrations of dissolved nutrients in river water, these conditions result in high phytoplankton growth rates in the near- and mid-field regions. Phytoplankton biomass rapidly accumulates and is maximal in the mid-field region. Microzooplankton grazers quickly respond and their biomass and grazing activities closely track the phytoplankton. As nutrient concentrations decline due to biological uptake and physical mixing with oligotrophic oceanic water, phytoplankton growth rates also decline. Phytoplankton stocks decline in this mid- to far-field region due to grazing losses and sinking. Because mesozooplankton grazers generally have a slower numerical response than microzooplankton, their importance as grazers is greatest in this mid- to far-field transition region, especially on large phytoplankton. Data reported in Liu \& Dagg (2003) support this conceptual model, and indicate that grazing from microzooplankton and mesozooplankton contributes to the observed changes in phytoplankton biomass and community structure.

The data in this paper further support the conceptual model in at least 3 ways: (1) abundance of microzooplankton (ciliates) was high in the near- to mid-field and then decreased toward the far-field, in parallel with phytoplankton stock; (2) mesozooplankton consumed large prey rather than small, thereby affecting the structure of the phytoplankton and microzooplankton communities; (3) phytoplankton, dominated by 
diatoms, were the major food source for mesozooplankton in the plume. However, more experiments are needed, especially in near-field (salinity $<20$ ) and far-field (salinity $>35$ ) regions, to refine the conceptual model of Dagg \& Breed (2003). We expect that as phytoplankton stock declines sharply in the far-field location, microzooplankton will remain relatively abundant, resulting in an increased importance of microzooplankton to the mesozooplankton diet.

Acknowledgements. We wish to thank D. Lawrence and J. Rabalais for technical assistance, and the captain and crew of the RV 'Pelican' for shipboard assistance. Comments from 4 anonymous reviewers helped improve the paper. This research was supported by NASA and the Louisiana Board of Regents through grant number NASA/LEQSF (2001-04), and by the Louisiana Universities Marine Consortium.

\section{LITERATURE CITED}

Atkinson A (1996) Subantarctic copepods in an oceanic, low chlorophyll environment: ciliate predation, food selectivity and impact on prey populations. Mar Ecol Prog Ser 130: 85-96

Banse K (1977) Determining the carbon-to-chlorophyll ratio of natural phytoplankton. Mar Biol 41:199-212

Bartram WC (1981) Experimental development of a model for the feeding of neritic copepods on phytoplankton. J Plankton Res 3:25-51

Batten SD, Fileman ES Halvorsen E (2001) The contribution of microzooplankton to the diet of mesozooplankton in an upwelling filament off the northwest coast of Spain. Prog Oceanogr 51:385-398

Berggreen U, Hansen B, Kiørboe T (1988) Food size spectra, ingestion and growth of the copepod Acartia tonsa during development: implications for determination of copepod production. Mar Biol 99:341-352

Chang J, Shiah FK, Gong GC, Chiang KP (2003) Cross-shelf variation in carbon-to-chlorophyll a ratios in the East China Sea, summer 1998. Deep-Sea Res II 50:1237-1247

Dagg MJ (1995) Ingestion of phytoplankton by the micro- and mesozooplankton communities in a productive subtropical estuary. J Plankton Res 17:845-857

Dagg MJ, Breed GA (2003) Biological effects of Mississippi River nitrogen on the northern Gulf of Mexico - a review and synthesis. J Mar Syst 43:133-152

Dagg MJ, Green EP, McKee BA, Ortner PB (1996) Biological removal of fine-grained lithogenic particles from a large river plume. J Mar Res 54:149-160

Fessenden L, Cowles TJ (1994) Copepod predation on phagotrophic ciliates in Oregon coastal waters. Mar Ecol Prog Ser 107:103-111

Flood PR, Deibel D, Morris C (1992) Filtration of colloidal melanin from seawater by planktonic tunicates. Nature 355:630-632

Fortier L, Le Fèvre J, Legendre L (1994) Export of biogenic carbon to fish and to the deep ocean: the role of large planktonic microphages. J Plankton Res 16:809-839

Froneman PW, Pakhomov EA, Perissinotto R, McQuaid CD (1996) Role of microplankton in the diet and daily ration of Antarctic zooplankton species during austral summer. Mar Ecol Prog Ser 143:15-23

Frost BW (1972) Effects of size and concentration of food par- ticles on the feeding behavior of the marine planktonic copepod Calanus pacificus. Limnol Oceanogr 18:805-815

Gifford DJ (1991) The protozoan-metazoan trophic link in pelagic ecosystems. J Protozool 38:81-86

Gifford DJ, Dagg MJ (1991) Feeding of the estuarine copepod Acartia tonsa Dana: carnivory vs herbivory in natural microplankton assemblages. Bull Mar Sci 43:458-468

Halvorsen E, Hirst AG, Batten SD, Tande KS. Lampitt RS (2001) Diet and community grazing by copepods in an upwelled filament off the NW coast of Spain. Prog Oceanogr 51:399-421

Jonsson PR, Tiselius P (1990) Feeding behavior, prey detection and capture efficiency of the copepod Acartia tonsa feeding on planktonic ciliates. Mar Ecol Prog Ser 60:35-44

Kiørboe T (1998) Population regulation and role of mesozooplankton in shaping marine pelagic food webs. Hydrobiologia 363:13-27

Kiørboe T, Saiz E, Viitasalo M (1996) Prey switching behaviour in the planktonic copepod Acartia tonsa. Mar Ecol Prog Ser 143:65-75

Kleppel GS (1992) Environmental regulation of feeding and egg production by Acartia tonsa off southern California. Mar Biol 112:57-65

Kleppel GS, Burkart CA, Carter K, Tomas C (1996) Diet of calanoid copepods on the West Florida shelf: relationships between food concentration, food composition and feeding activity. Mar Biol 127:209-217

Liu H, Dagg MJ (2003) Interactions between nutrients, phytoplankton growth, and micro- and mesozooplankton grazing in the plume of the Mississippi River. Mar Ecol Prog Ser 258:31-42

Lohrenz SE, Fahnenstiel GL, Redalje DG, Lang GA (1992) Regulation and distribution of primary production in the northern Gulf of Mexico. In: NOAA Coastal Ocean Program (ed) Nutrient Enhanced Coastal Ocean Productivity, (NECOP) Workshop Proceedings, October 1991. Texas Sea Grant Publication, TAMU-SG-92-109, Texas A\&M University Press, College Station, TX, p 95-104

Martin JL, Haya K, Burridge LE, Wildish DJ (1990) Nitzschia pseudodelicatissima - a source of domoic acid in the Bay of Fundy, eastern Canada. Mar Ecol Prog Ser 67:177-182

Nejstgaard JC, Gismervik I, Solberg PT (1997) Feeding and reproduction by Calanus finmarchicus, and microzooplankton grazing during mesocosm blooms of diatoms and the coccolithophore Emiliania huxleyi. Mar Ecol Prog Ser 147:197-217

Ohman MD, Runge JA (1994) Sustained fecundity when phytoplankton resources are in short supply: omnivory by Calanus finmarchicus in the Gulf of St. Lawrence. Limnol Oceanogr 39:21-36

Ortner PB, Dagg MJ (1995) Nutrient-enhanced coastal ocean productivity explored in the Gulf of Mexico. EOS Trans Am Geophy Un 76:97-109

Ota T, Taniguchi A (2003) Standing crop of planktonic ciliates in the East China Sea and their potential grazing impact and contribution to nutrient regeneration. Deep-Sea Res II 50:423-442

Paffenhöfer GA (1988) Feeding rates and behavior of zooplankton. Bull Mar Sci 43:430-445

Pan Y, Parsons ML, Busman M, Moeller PDR, Dortch Q, Powell CL, Doucette GJ (2001) Pseudo-nitzschia sp. cf. pseudodelicatissima - a confirmed producer of domoic acid from the northern Gulf of Mexico. Mar Ecol Prog Ser 220: $83-92$

Pielou EC (1984) The interpretation of ecological data. John Wiley \& Sons, New York

Putt M, Stoecker DK (1989) An experimentally determined 
carbon:volume ratio for marine 'oligotrichous' ciliates from estuarine and coastal waters. Limnol Oceanogr 34: 1097-1107

Richman S, Heinle DR, Huff R (1977) Grazing by adult estuarine calanoid copepods of the Chesapeake Bay. Mar Biol 42:69-84

Rollwagen Bollens GC, Penry DL (2003) Feeding dynamics of Acartia spp. copepods in a large, temperate estuary (San Francisco Bay, CA). Mar Ecol Prog Ser 257:139-158

Sanders RW, Wickham SA (1993) Planktonic protozoa and metazoa: predation, food quality and population control. Mar Microb Food Webs 7:197-223

Sherr EB, Sherr BF (1988) Role of microbes in pelagic food webs: a revised concept. Limnol Oceanogr 33:1225-1227

Sherr EB, Sherr BF, Paffenhöfer GA (1986) Phagotrophic protozoa as food for metazoans: a 'missing' trophic link in marine pelagic food webs? Mar Microb Food Webs 1: 61-80

Stoecker DK, Capuzzo JM (1990) Predation on protozoa: its importance to zooplankton. J Plankton Res 12:891-908

Stoecker DK, Egloff DA (1987) Predation by Acartia tonsa Dana on planktonic ciliates and rotifers. J Exp Mar Biol Ecol 110:53-68

Editorial responsibility: Otto Kinne (Editor-in-Chief), Oldendorf/Luhe, Germany
Strom SL, Strom MW (1996) Microplankton growth, grazing, and community structure in the northern Gulf of Mexico. Mar Ecol Prog Ser 130:229-240

Tett P, Wilson H (2000) From biogeochemical to ecological models of marine microplankton. J Mar Syst 25:431-446

Utermöhl H (1958) Zur Vervollkommnung der quantitativen Phytoplankton Methodik. Mitt Int Ver Theor Angew Limnol 9:1-38

Verity PG, Langdon C (1984) Relationships between lorica volume, carbon, nitrogen, and ATP content of tintinids in Narragansett Bay. J Plankton Res 6:859-868

Verity PG, Paffenhöfer GA (1996) On assessment of prey ingestion by copepods. J Plankton Res 18:1767-1779

Vincent D, Hartmann HJ (2001) Contribution of ciliated microprotozoans and dinoflagellates to the diet of three copepod species in the Bay of Biscay. Hydrobiologia 443: 193-204

Wiseman WJ Jr, Murray SP, Bane JM, Tubman MW (1982) Temperature and salinity variability within the Louisiana Bight. Contrib Mar Sci 25:109-120

Zeldis JR, James MR, Grieve J, Richards L (2002) Omnivory by copepods in the New Zealand Subtropical Frontal Zone. J Plankton Res 24:9-23

Submitted: May 11, 2004; Accepted: September 14, 2004 Proofs received from author(s): January 24, 2005 